\title{
Divergent effects of nitric oxide on airway epithelial cell activation
}

\author{
Tommaso Neri", Ilaria Conti, Chiara Cerri, Laura Tavanti, Pierluigi Paggiaro and Alessandro Celi
}

Laboratorio di Biologia Cellulare Respiratoria, Dipartimento Cardiotoracico e Vascolare, University of Pisa, Pisa, Italy.

\begin{abstract}
Nitric oxide $\left(\mathrm{NO}^{\bullet}\right)$ is a gaseous mediator synthesized by nitric oxide sinthases. $\mathrm{NO}^{\bullet}$ is involved in the modulation of inflammation, but its role in airway inflammation remains controversial. We investigated the role of $\mathrm{NO}^{\bullet}$ in the synthesis of the chemokines Interleukin-8 and Monocyte Chemotactic Protein-1, and of Intercellular Adhesion Molecule-1 by human airway epithelial cells. Normal human bronchial epithelial cells and the bronchial epithelial cell line BEAS-2B were used. Ineterleukin-8 (IL-8) and Monocyte Chemotactic Protein-1 (MCP-1) secretion and Intercellular Adhesion Molecule-1 (ICAM-1) expression were measured by ELISA. mRNA was assessed by semiquantitative RT-PCR. Ineterleukin-8 secretion was significantly reduced after $24 \mathrm{~h}$ incubation with the NO• donor, sodium nitroprusside. The effect was dose-dependent. Similar results were obtained with S-Nitroso-N-D,L-penicillamine and SNitroso-L-glutathione. Inhibition of endogenous $\mathrm{NO}^{\bullet}$ with the nitric oxide synthase inhibitor N-Nitro-L-arginine-methyl-esther caused an increase in IL-8 secretion by lypopolisaccharide- and cytokine-stimulated BEAS-2B cells. Sodium nitroprusside also caused a reduction in Monocyte Chemotactic Protein-1 secretion by both cell types. In contrast, Intercellular Adhesion Molecule-1 expression was upregulated by sodium nitroprusside. RT-PCR results indicate that the modulation of protein levels was paralleled by modification in mRNA levels. $\mathrm{NO}^{\bullet}$ has divergent effects on the synthesis of different inflammatory mediators in human bronchial epithelial cells.
\end{abstract}

Key terms: Adhesion molecules, Airway inflammation, Alveolar Epithelium, Chemokines, Nitric Oxide

\section{INTRODUCTION}

Nitric Oxide $\left(\mathrm{NO}^{\bullet}\right)$ is a highly reactive oxygen species identified with the endothelium derived relaxing factor (Moncada et al., 1988). More recently, however, numerous biological activities besides vascular relaxation have been attributed to $\mathrm{NO}^{\bullet}$. Many of these activities are related to the regulation of the inflammatory process, including modulation of the synthesis of cytokines by endothelial cells (De Caterina et al., 1995, Villarete and Remick, 1995, Natarajan et al., 2001) and by monocytes/macrophages (Lander et al., 1993, Ma et al., 2004), down-regulation of neutrophil aggregation and secretion (May et al., 1991), down-regulation of the release of inflammatory mediators by mast cells (van Overveld et al., 1993), prevention of superoxide production by neutrophils (Clancy et al., 1992). $\mathrm{NO}^{-}$is synthesized from L-arginine through the action of a family of enzymes called $\mathrm{NO}^{\bullet}$ synthases (NOS). NOS are expressed by numerous cells, including macrophages, neurons, islets, skeletal muscle cells, and endothelial cells (reviewed in (Murad, 2006)).

Once perceived as a passive barrier, in fact the airway epithelium plays a critical role in the maintenance of airway homeostasis. Among other functions, the epithelium lining the airways contributes to the innate immune system through the synthesis and expression of a variety of molecules, including an array of adhesion molecules and soluble mediators involved in the recruitment and activation of inflammatory leukocytes. Through the action of these mediators, the airway epithelium participates actively in the defense against airborne pathogens, as well as in the orchestration of the inflammatory reactions that characterize several pulmonary diseases (Bals and Hiemstra, 2004).
Airway epithelial cells have been demonstrated to express all three isoforms of NOS (Sherman et al., 1999). This, and the observation that fractional exhaled $\mathrm{NO}^{\bullet}\left(\mathrm{FE}_{\mathrm{NO}}\right)$ varies in pulmonary diseases, including asthma and chronic obstructive pulmonary disease (COPD) (Kharitonov and Barnes, 2006, Abba, 2009), have prompted several studies aimed at investigating the specific role of this molecule in airway inflammation. However, data from animal models have been somewhat contradictory, showing both proinflammatory and anti-inflammatory actions (reviewed in(van der Vliet et al., 2000)(Liu et al., 2007)).

In an attempt to further clarify some aspects of $\mathrm{NO}^{*}$ involvement in airway inflammation, we investigated in vitro the effect of this molecule on the synthesis of inflammatory mediators by human bronchial epithelial cells.

\section{MATERIALS AND METHODS}

Reagents

The mouse anti-human-ICAM-1 monoclonal antibody (clone 15.2) was obtained from Ancell (Bayport, MN, USA). Formaldehyde, o-phenylendiamine (OPD), Bovine Serum Albumin (BSA), Trypan blue, N-Nitro-L-arginine-methylesther (L-NAME), lypopolysaccharide (E. Coli, serotype 0111:B4, LPS), Griess reagent (modified), N-[2Hydroxyethyl] piperazine- $\mathrm{N}^{\prime}$-[2-ethane sulfonic acid] (Hepes), Dulbecco phosphate buffer saline (PBS), Hanks' Balanced Salt Solution (HBSS), In Vitro Toxicology Assay Kit XTT based, Ethidium Bromide, Agarose, REDTaq genomic DNA Polymerase SuperPak and DNA ladder, direct load 100bp, RPMI 1640, Fetal Bovine Serum (FBS), Penicillin/Streptomicine, Trypsin/EDTA, L-Glutamine Peroxidase-conjugate anti-mouse IgG ( $\gamma$-chain specific) and

* Corresponding Author: Tommaso Neri, PhD, Dipartimento Cardiotoracico e Vascolare, Via Paradisa, 2, 56124 Pisa, Italy, Phone: (+) 39050996946, Fax: (+) 39 050 996947 , Email: t.neri@med.unipi.it 
interferon- $\gamma$ (IFN- $\gamma$ ) were obtained from Sigma Chemical Co. (Milan, Italy). Human recombinant Tumor Necrosis Factor-a (TNF- $\alpha)$ (cell culture grade) was obtained from Alexis, (Vinci, Florence, Italy). Recombinant Human MCP-1 was obtained from Inalco (Italy). The chromogenic substrate $3,3^{\prime}, 5,5^{\prime}$-Tetramethylbenzidine (TMB) was obtained from Calbiochem (San Diego, CA). Human MCP-1 Module Set was obtained from Bender Medsystems $\mathrm{GmbH}$ (Vienna, Austria). IL-8 Flexia was obtained from Biosource International (Camarillo, USA). Sensiscript reverse Transcriptase for First Strand c-DNA kit was obtained from Qiagen (Milan, Italy). S-Nitroso-N-D,L-penicillamine (SNAP) and S-Nitroso-Lglutatione (GSNO) were obtained from Alexis (Vinci, Florence, Italy). Sodium nitroprusside (SNP) was obtained from Malesci Pharmacology Institute S.p.A. (Florence, Italy). Reagent Pack (Trypsin/EDTA, Trypsin Neutralizing Solution, Hepes buffered saline solution) and BEGM BulletKit were obtained from Cambrex (Caravaggio, BG, Italy).

\section{RT-PCR Primers}

The sense and antisense primers for human IL-8, MCP-1, ICAM-1 and GAPDH were obtained from Invitrogen (Milan, Italy). Primer sequences:

\section{IL-8: Sense: ATGACTTCCAAGCTGGCCGT Antisense: CCTCTTCAAAAACTTCTCCACACC MCP-1 Sense: GCCTCCAGCATGAAAGTCTC Antisense: CAGATCTCCTTGGCCACAAT ICAM-1 Sense: GGCTGGAGCTGTTTGAGAAC Antisense ACTGTGGGGTTCAACCTCTG GAPDH: Sense: CGATGCTGGCGCTGAGTA Antisense: CGTTCAGCTCAGGGATGACC}

Cells

Human BEAS-2B cells (American Type Culture Collection CRL-9609) were kindly provided by Dr. Stefano Carnevali, University of Modena, Italy. BEAS-2B cells were grown in 75 $\mathrm{cm}^{2}$ cell culture flasks in RPMI 1640:BEGM (1:1 vol:vol) in a humidified $95 \%$ air- $5 \% \mathrm{CO}_{2}$ atmosphere at $37^{\circ} \mathrm{C}$. BEAS-2B cells were used at passage 80-83. Normal human bronchial epithelial cells (NHBEC) were obtained from Cambrex Bioscience (Milan, Italy) and grown in BEGM medium according to the supplier's instructions. NHBEC were used at passages 1-4.

NO donors and NOS inhibitors treatment of cells

Cells were cultured on 24- or 96-well plates until they reached $70 \%$ confluence. Cells were then washed and the medium was replaced with fresh medium containing the indicated reagents. The supernatants were then collected from the wells after 24 hours of incubation.

\section{ELISA for chemokine detection}

IL-8 and MCP-1 in supernatants from NO donor-treated NHBEC and BEAS-2B cells were measured by sandwich ELISA using the IL-8 Flexia kit and the human MCP-1 module according to the manufacturers' instructions.

\section{RT-PCR}

RNA was extracted from the cells using the Qiagen RNeasy kit according to the manufacturer's instructions. RNA concentration and purity were determined by spectrophotometric readings at $260 / 280 \mathrm{~nm}$. RNA was then stored at $-80^{\circ} \mathrm{C}$ for further uses. The RNA to cDNA reverse transcription was performed using the Invitrogen Sensiscript Reverse Transcriptase First-Strand DNA Synthesis Kit according to the manufacturer's instructions. The obtained cDNA was amplified by PCR using specific primers for IL-8, MCP-1, ICAM-1 and GAPDH or stored at $20^{\circ} \mathrm{C}$ for further use. PCR reactions were set up using the Sigma RedTaq DNA polymerase kit. Amplification products were run on $1.5 \%$ agarose gel with $0.001 \%$ Ethidium Bromide. PCR conditions: IL-8: $94^{\circ} \mathrm{C}$ for $60^{\prime \prime}, 55^{\circ} \mathrm{C}$ for $60^{\prime \prime}, 72^{\circ} \mathrm{C}$ for $60^{\prime \prime}$, for 35 times followed by $72^{\circ}$ for $7^{\prime}$ then storage at $4^{\circ} \mathrm{C}$; MCP- 1 : $94^{\circ} \mathrm{C}$ for $55^{\prime \prime}$ $60^{\circ} \mathrm{C}$ for $45^{\prime \prime}, 72^{\circ} \mathrm{C}$ for $45^{\prime \prime}$, for 30 times followed by $72{ }^{\circ} \mathrm{C}$ for $7^{\prime}$ and storage at $4^{\circ} \mathrm{C}$; ICAM-1: $94^{\circ} \mathrm{C}$ for $30^{\prime \prime}, 60^{\circ} \mathrm{C}$ for $30^{\prime \prime}$, $72^{\circ} \mathrm{C}$ for $30^{\prime \prime}$ for 35 times followed by $72^{\circ}$ for $7^{\prime}$ and storage at $4{ }^{\circ} \mathrm{C}$; GAPDH: $95^{\circ} \mathrm{C}$ for $5^{\prime}$, then $94^{\circ} \mathrm{C}$ for $45^{\prime \prime}, 58^{\circ} \mathrm{C}$ for $45^{\prime \prime}$, $72^{\circ} \mathrm{C}$ for $45^{\prime \prime}$ for 35 times, followed by $72^{\circ} \mathrm{C}$ for $5^{\prime}$ and storage at $4^{\circ} \mathrm{C}$. Band intensity was calculated using image analysis software (IMAGEJ version 1.42q, NIH, Bethesda, MD, USAs).

Measurement of cell surface intercellular adhesion molecule-1 (ICAM1) expression

ICAM-1 expression on HEBC and BEAS-2B cells was measured by direct cell ELISA as described with minor modifications (Celi et al., 1999). Briefly, cells were seeded at $7.510^{4}$ cells/well in $0.1 \mathrm{ml}$ of medium in 96-well plates. When the cells reached subconfluence, they were washed three times with HBSS and fixed with $3.7 \%$ formaldehyde $(\mathrm{w} / \mathrm{v})$. Following additional extensive washing, nonspecific $\mathrm{Ab}$ binding sites were blocked by incubating the cells with HBSS/ $2 \%$ BSA $(\mathrm{w} / \mathrm{v})$ for $2 \mathrm{~h}$. Cells were then incubated with mouse anti human ICAM-1 Ab $(5 \mathrm{mg} / \mathrm{ml})$ in HBSS $0.5 \%$ BSA $(w / v)$ for $2 \mathrm{~h}$ at $37^{\circ} \mathrm{C}$, then washed three times with wash buffer. Peroxidase-conjugated antimouse IgG Ab was then added at the concentration recommended by the manufacturer and incubated for $1 \mathrm{~h}$ at $37^{\circ} \mathrm{C}$. After extensive washing, bound enzyme was determined by adding o-phenylendiamine, $1 \mathrm{mg} /$ $\mathrm{ml}$ in $50 \mathrm{mM}$ sodium citrate $(\mathrm{pH} 4)$, containing $0.015 \% \mathrm{H}_{2} \mathrm{O}_{2}$. After blocking the reaction with $2 \mathrm{M} \mathrm{H}_{2} \mathrm{SO}_{4}$, the plate was read in a spectrophotometer (Titertek Multiskan MCC ELISA reader; Flow Laboratories) at $492 \mathrm{~nm}$.

\section{Cell viability assays}

Cell viability after treatment with different $\mathrm{NO}^{\bullet}$ donors was assessed using the In Vitro Toxicology XTT-based Assay Kit, according to the manufacturer's instructions. Except for the dose-response experiments, the concentrations of $\mathrm{NO}^{\bullet}$ donors used in all other experiments were the highest that did not not cause any detectable loss in viability.

\section{Nitrate production assay}

Nitrate concentration in cell culture supernatants was measured using the Griess reagent according to the manufacturer's instructions. 
Data presentation and statistical analysis

Unless otherwise indicated, data are shown as mean \pm SEM of $\mathrm{n}$ independent cultures. Comparisons between groups were made by the paired Student's t test using Prism Software (GraphPad, San Diego, Ca). Values of $p<0.05$ were considered statistically significant.

\section{RESULTS}

Exogenous NO induces a decrease in IL-8 secretion by human bronchial epithelial cells

SNP causes an increase in nitrate concentration in the experimental conditions used, as expected (fig. 1).

Human Bronchial Epithelial Cells constitutively secrete IL-8, confirming data from other groups (Devalia et al., 1993, Mio et al., 1997). Treatment of both NHBEC and BEAS-2B cells with SNP induced a significant decrease in constitutive IL-8 secretion as assessed by ELISA; similar results were obtained with different $\mathrm{NO}^{-}$donors (Fig. 2 A and B, respectively). This inhibition was dose-dependent (Fig. 3). The NO-mediated inhibition of IL-8 secretion by human bronchial epithelial cells is not due to direct toxicity of the $\mathrm{NO}^{\bullet}$ donors at the concentrations used, as assessed by XTT cell viability assays (not shown). Semiquantitative RT-PCR results suggest that $\mathrm{NO}^{\bullet}$ induces a reduction in IL-8 mRNA levels in BEAS-2B cells (Fig. 2C).

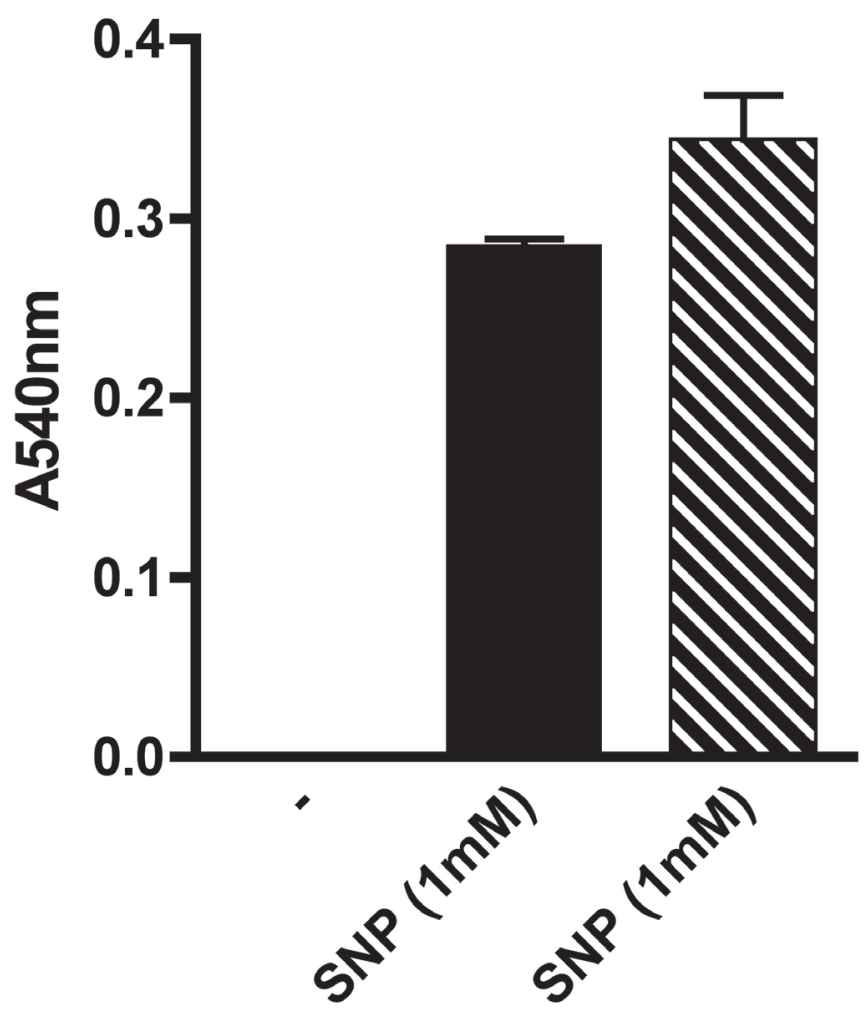

Figure 1: Effect of SNP on nitrate production in NHBEC (solid bar) and in BEAS-2B cells (hatched bar). Nitrate levels were measured using Griess reaction in supernatants of cells treated with SNP for 24 hours.
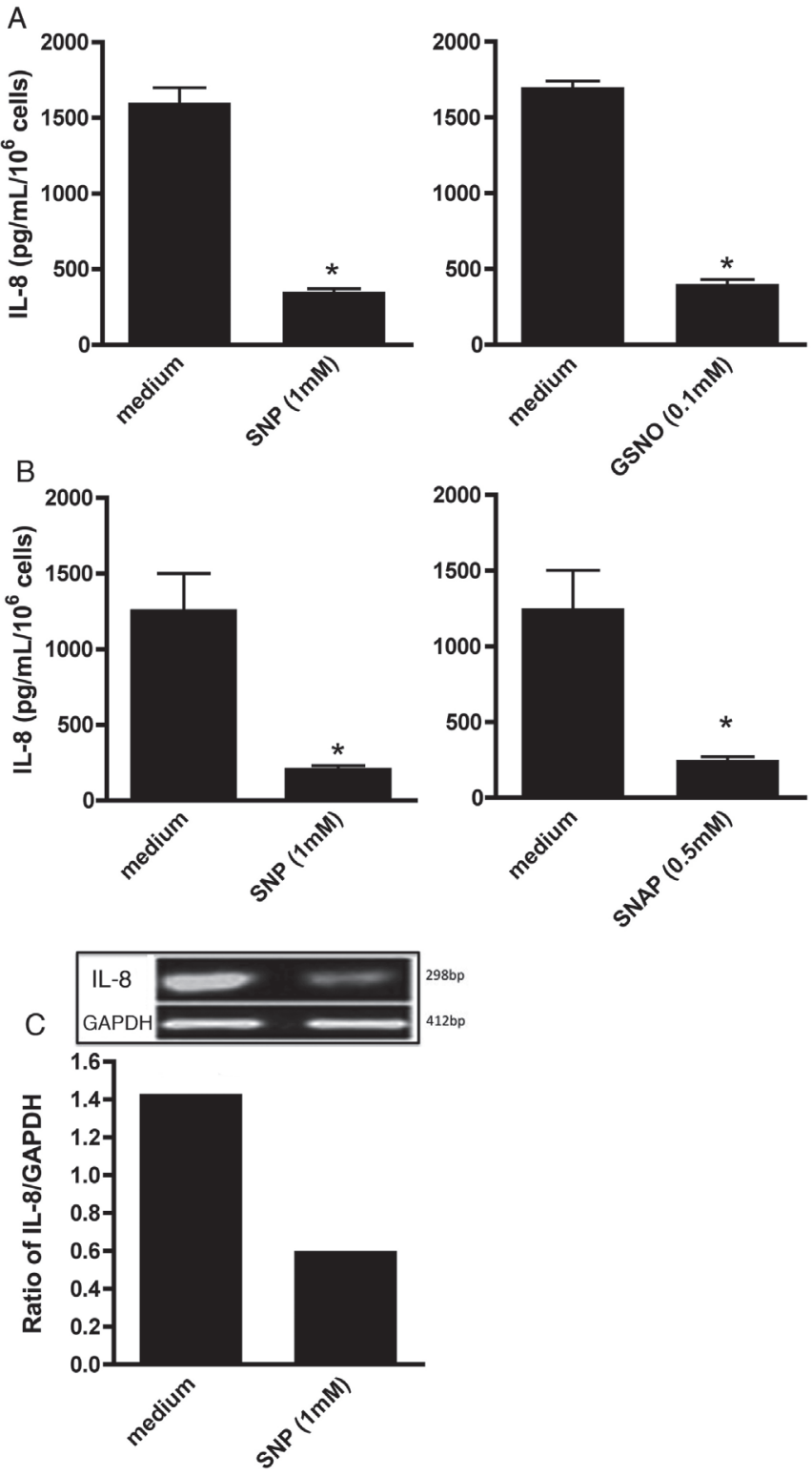

Figure 2: NO reduces IL-8 secretion by bronchial epithelial cells. NHBEC $(A)$ and BEAS-2B cells (B and C), were incubated with the indicated NO donors for 24 hours prior to IL- 8 assay. Panel $C$ represents RT-PCR analysis of IL-8 and GAPDH mRNA from untreated and SNP-treated BEAS-2B cells (cDNA form one representative culture). *: $\mathrm{p}<0.05$, Student's t-Test; $\mathrm{n}=7$

Inhibition of endogenous NO induces an increase in IL-8 secretion by human bronchial epithelial cells

Treatment of BEAS-2B cells with the NOS inhibitor, LNAME, did not induce any significant variation in baseline IL-8 production. However, since constitutive $\mathrm{NO}^{\bullet}$ production, as assessed by the Griess assay, is very low (data not shown), we treated the cells with LPS or with a LPS 10 $\mu \mathrm{g} / \mathrm{ml}, \mathrm{TNF}-\alpha 1000 \mathrm{U} / \mathrm{ml}$, IFN- $\gamma 100 \mathrm{U} / \mathrm{ml}$ mixture (cytomix) in order to induce NOS activity, and we tested the effect of L-NAME on treated cells. L-NAME treatment induced a significant upregulation of IL-8 secretion by LPS and cytomix treated cells compared to that of cells treated in the absence of the NOS inhibitor (Fig. 4). 
NO ${ }^{\bullet}$ induces a decrease in MCP-1 secretion by human bronchial epithelial cells

Treatment with SNP downregulated MCP-1 secretion by both NHBEC and BEAS-2B cells (Fig. $5 \mathrm{~A}$ and B, respectively). This decrease in protein secretion was paralleled by a reduction of MCP-1 mRNA presence as estimated by semiquantitative RT-PCR (Fig. 5C).

NO• upregulates ICAM-1 synthesis and expressione by bronchial epithelial cells

Treatment with SNP caused an increase in ICAM-1 expression, as assessed by c-ELISA, in both NHBEC and BEAS2B cells (Fig. $6 \mathrm{~A}$ and $\mathrm{B}$, respectively). Semiquantitative RT-PCR results suggest that the increase in protein expression is paralleled by an increase in mRNA (Fig 6C).

\section{DISCUSSION}

Our data show that $\mathrm{NO}^{-}$has divergent effects on the synthesis of IL-8, MCP-1 and ICAM-1 by human airway epithelial cells. Exogenous $\mathrm{NO}^{\bullet}$ caused a significant inhibition of constitutive chemokine synthesis, and an increase in ICAM-1 synthesis measured at both the protein and the mRNA level. Although most of the experiments were carried out with SNP, two other structurally unrelated molecules capable of liberating $\mathrm{NO}$ in aqueous solutions, GSNO and SNAP, were used as $\mathrm{NO}^{\bullet}$ donors in selected experiments. In these experiments, the three compounds yielded comparable results, thus corroborating the hypothesis that $\mathrm{NO}^{*}$, rather that (an)other component(s) of the molecules was responsible for the effect. Cell viability assays ruled out the possibility that the inhibitory effect seen with chemokines was the result of direct toxicity.

Since airway epithelial cells synthesize $\mathrm{NO}^{\bullet}$ through NOS (Watkins et al., 1997), we also investigated the potential

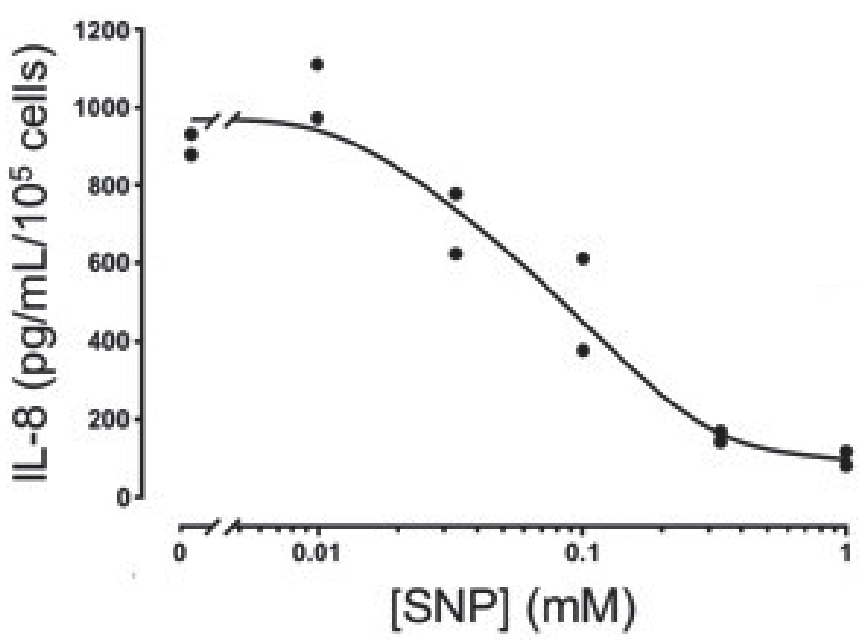

Figure 3: Dose response of $\mathrm{NO}^{\circ}$-induced inhibition of IL-8 secretion by bronchial epithelial cells. BEAS-2B cells were incubated with increasing concentrations of the NO- donor, SNP, for 24 hours prior to IL-8 assay. Data from one experiment representative of two. The fit line was calculated from a certain equation using Prism Software (GraphPad, San Diego, Ca). role of endogenous $\mathrm{NO}^{*}$ in regulating IL-8 synthesis. Inhibition of NOS with L-NAME had no effect on constitutive IL-8 secretion. This is not surprising in light of the observation that baseline production of $\mathrm{NO}^{-}$is hardly detectable under these conditions and, therefore, inhibition of its synthesis would be expected not to have any effect. However, when cells were treated with LPS, an agonist known to induce both IL-8 and NOS synthesis by airway epithelial cells (Watkins et al., 1997, Laan et al., 2004), we observed an upregulation of IL-8 secretion only in the presence of L-NAME. This result suggests that the direct stimulatory effect on IL-8 synthesis by LPS, at the concentration used in our experiments, is counterbalanced by an increase in $\mathrm{NO}^{\bullet}$ production, in turn mediated by the upregulation of NOS synthesis; when $\mathrm{NO}^{\bullet}$ synthesis is inhibited by L-NAME, the net effect is shifted toward the upregulation of IL-8 synthesis. Similar results were obtained with a more potent stimulus, namely the combination of LPS with a mixture of cytokines; these agonists did cause an upregulation in IL-8 synthesis in the absence of L-NAME but their stimulatory effect was significantly higher in its presence. Our observation of a reduction in mRNA levels for IL-8 and MCP-1 in bronchial epithelial cells in response to exogenous $\mathrm{NO}^{\bullet}$, albeit only semitquantitative, is compatible with a direct transcriptional effect, possibly due to a NF-кB inhibition by $\mathrm{NO}^{\bullet}$, which has been previously reported (De Caterina et al., 1995). However, the regulatory role of $\mathrm{NO}^{\bullet}$ must be more complex, since in our hands the expression of another protein whose synthesis is mediated by NF- $\kappa$ B, ICAM-1 (Amrani et al., 1999), is upregulated by NO. Our data are in apparent contrast to those obtained by Sparkman and Boggaram that show that $\mathrm{NO}^{\bullet}$ increases IL-8 gene transcription and mRNA stability in lung epithelial cells

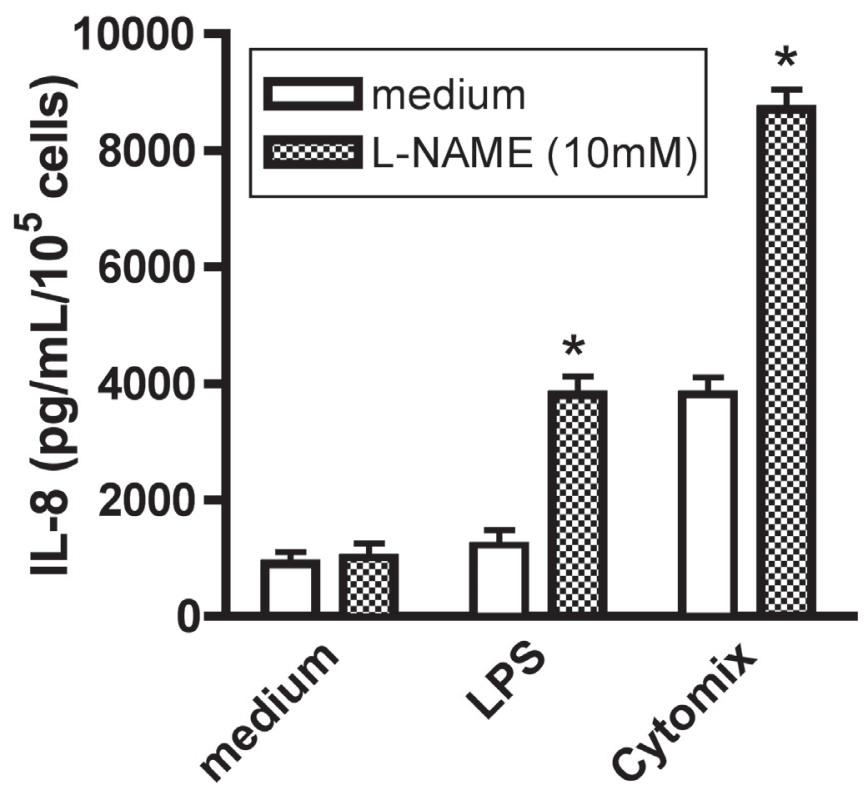

Figure 4: NOS inhibition increases IL-8 secretion by human bronchial epithelial cells. BEAS-2B cells were incubated with medium, LPS $(10 \mu \mathrm{g} / \mathrm{ml})$, or cytomix (LPS, $10 \mu \mathrm{g} / \mathrm{ml}$; TNF- $\alpha$, $1000 \mathrm{U} / \mathrm{ml}$; IFN- $\gamma, 100 \mathrm{U} / \mathrm{ml}$ ) for 24 hours, in the presence and in the absence of the NOS inhibitor, L-NAME (10 nM). *: $p<0.05$ for L-NAME treated vs. untreated cells, Student's t-Test; $n=3$ 
(Sparkman and Boggaram, 2004). Indeed, based on that data, it is now commonly accepted that $\mathrm{NO}^{\bullet}$ upregulates cytokine expression by airway epithelial cells (Bove and van der Vliet, 2006). However, it should be noted that the results published by Sparkman were obtained using a malignant cell line (H441), derived from a patient with lung adenocarcinoma. The use of malignant cell lines to infer the biological properties of the normal cells from which they were derived is potentially misleading, and data obtained with the former should not automatically be transferred to the latter. For example, Loewen and coworkers have compared the responsiveness to inflammatory cytokines of normal bronchial epithelial cells to that of metaplastic, dysplastic, or frankly malignant cells and to that of established malignant cell lines, including H441. They showed that the process of malignant transformation induced modifications in the activities of signal transduction pathways activated by cytokines, such as an increase in ERK phosphorilation, and that these modifications were similar to those seen in established lung cancer cell lines (Loewen et al., 2005).

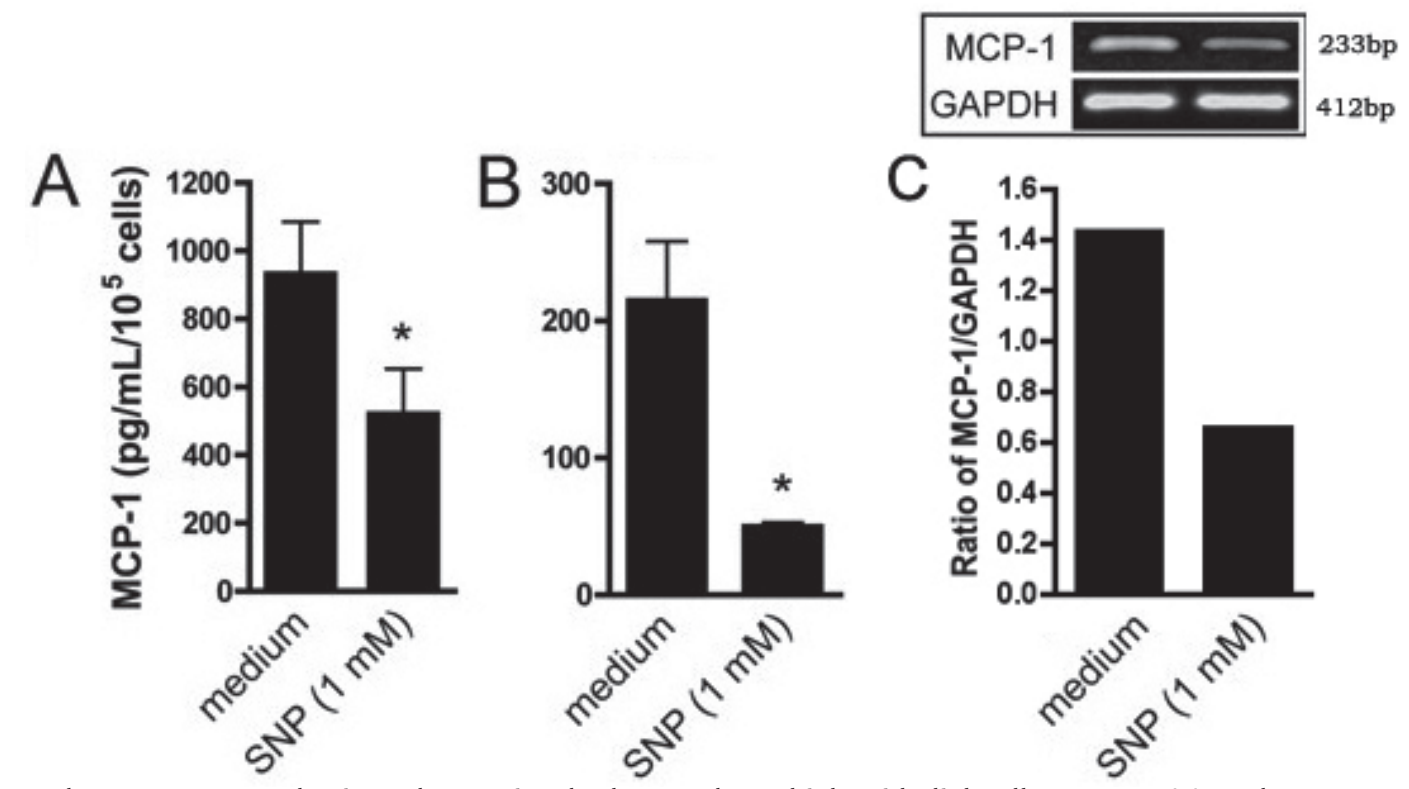

Figure 5: NO• reduces MCP-1 synthesis and secretion by human bronchial epithelial cells. NHBEC (A) and BEAS-2B cells (B and C) were incubated with SNP for 24 hours prior to MCP-1 assay. Panel C represent RT-PCR analysis of MCP-1 and GAPDH mRNA from untreated and SNP-treated BEAS-2B cells (cDNA from one representative culture). *: $\mathrm{p}<0.05$, Student's $\mathrm{t}$-Test; $\mathrm{n}=3$
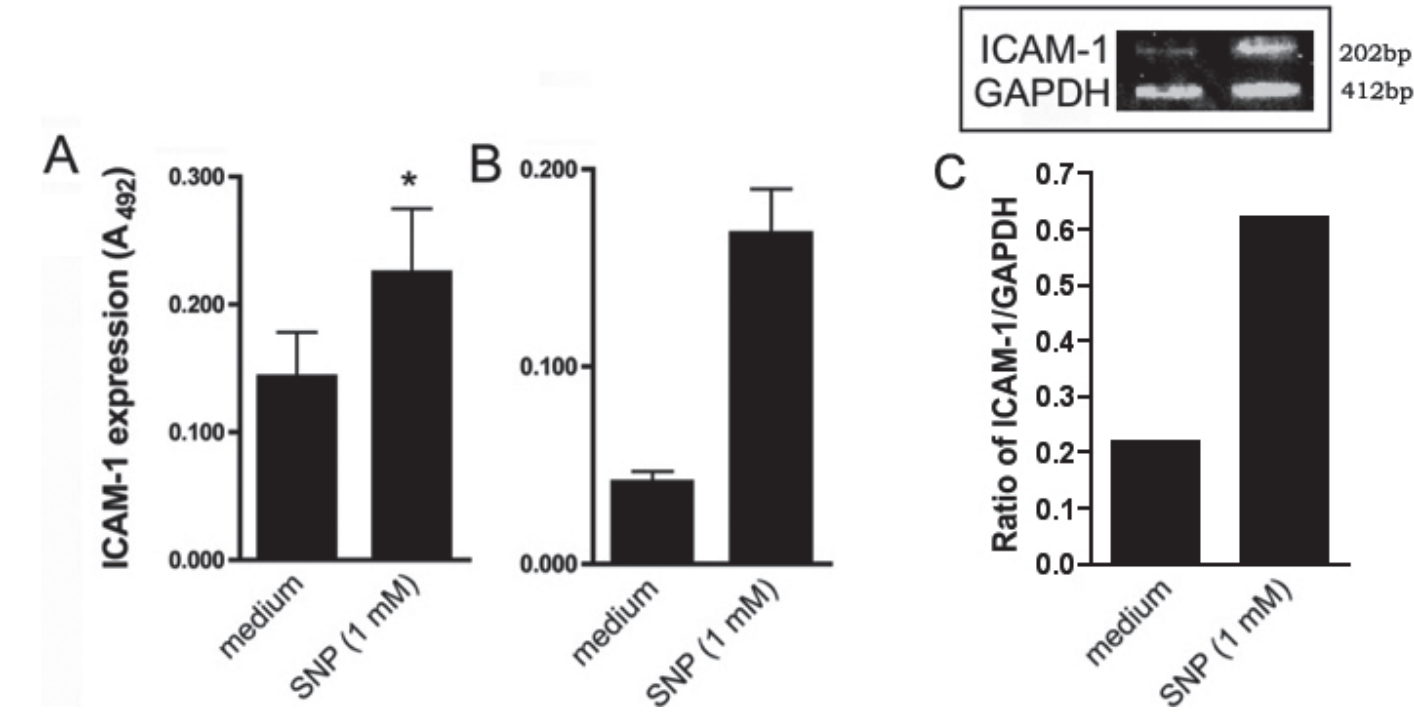

Figure 6: NO upregulates ICAM-1 expression by human bronchial epithelial cells. NHBEC (A) and BEAS-2B cells (B and C) were incubated with SNP for 24 hours prior to CELISA for ICAM-1 determination. Panel C represent RT-PCR analysis of ICAM- 1 and GAPDH mRNA from untreated and SNP-treated BEAS-2B cells (cDNA from one representative culture). *: $p<0.05$ for SNP treated vs. untreated BEAS-2B cells, Student's t-Test; $n=4$ Data for NHBEC are mean \pm SD of 4 replicate wells from one experiment representative of two. 
Studies on the modulation of IL-8 synthesis by endothelial cells induced by $\mathrm{NO}^{\bullet}$ have yielded opposite results when normal human endothelial cells (De Caterina et al., 1995) and cells of the line ECV304 were used (Villarete and Remick, 1995), showing an inhibition and an upregulation of IL-8 synthesis, respectively. Thus, the apparent discrepancy between our results and those obtained by Sparkman is likely due, at least in part, to differences in the cell model. While Sparkman and Boggaram also describe similar results obtained with BEAS-2B cells, these data are not shown in the paper, making direct comparisons difficult. In the current study, we used two different cell types, both of non malignant origin. BEAS-2B cells are widely used as a model of lung epithelial cell biology, but they are an immortal cell line, so that some critical biological properties might have been changed by SV40 transformation. In contrast, normal bronchial epithelial cells do not share this potential problem, but because they are harvested from a very limited number of donors, data obtained with these cells might be difficult to generalize. While most of the experiments reported in this study were performed with BEAS-2B cells for practical reasons, some critical results were confirmed with NHBEC. $\mathrm{NO}^{\bullet}$ is a well-established mediator involved in inflammatory lung diseases, and physicians have long been known to use $\mathrm{FE}_{\mathrm{NO}}$ as a biomarker of lung inflammation (Kharitonov and Barnes, 2006). However, the exact molecular basis of its effects on the airways are far from being completely elucidated, and whether $\mathrm{NO}^{\bullet}$ has favorable or detrimental effects on normal lung function remains a matter of debate. For example, in a swine model of lung injury, inhaled $\mathrm{NO}^{*}$ inhibits transendothelial migration of neutrophils into the airways (Bloomfield et al., 1997). Genetically engineered mice lacking inducible NOS (iNOS, NOS2) appear more resistant than wild-type mice to LPS-induced acute lung injury (Kristof et al., 1998). Speyer and collaborators have shown that the concentration of MCP-1 in the bronchoalveolar lavage fluid after LPS instillation is significantly higher in iNOS $^{-/-}$mice than in wild-type animals, suggesting that $\mathrm{NO}^{\bullet}$ might exert antiinflammatory effects through the inhibition of MCP-1 synthesis. Indeed, they confirmed in ex vivo experiments that LPS-IFN- $\gamma$ induced MCP-1 synthesis is increased in both dermal microendothelial cells and peritoneal macrophages derived from iNOS $^{-/}$animals compared to wild-type controls (Speyer et al., 2003). Proinflammatory effects of $\mathrm{NO}^{\bullet}$ in animal models have also been reported. $\mathrm{NO}^{\bullet}$ generated from endothelial NOS (eNOS, NOS3) was shown to contribute to bronchial hyperresponsiveness and inflammation in a murine model of asthma (De Sanctis et al., 1999). iNOS - $^{-}$ mice were reported to be less sensitive to the asthma-like manifestations induced by ovalbumin (OVA) challenge compared to controls. The observation that lung $\mathrm{T}$ cells isolated from iNOS ${ }^{-/-}$OVA challenged mice generate more IFN $-\gamma$ than those obtained from control animals might contribute to explaining these results (Xiong et al., 1999). These data were recently confirmed in a guinea pig model of OVA sensitization in which it was shown that treatment with the specific iNOS inhibitor, $1400 \mathrm{~W}$, attenuated bronchoconstriction and inflammatory and remodeling processes (Prado et al., 2006). While animal models have the potential to provide priceless information on the role of $\mathrm{NO}^{*}$ in biologically relevant, complex systems, they also suffer from the shortcoming that they often do not allow to single out the effects at the single cell type level. Furthermore, animal models do not necessarily reflect human diseases. Several studies have also addressed the issue of the role of $\mathrm{NO}^{\circ}$ in airway inflammation in humans. As mentioned above, an increase in $\mathrm{NO}^{\circ}$, measured, either through its endproducts, nitrite and nitrate, or as $\mathrm{FE}_{\mathrm{NO}}$, has been shown to correlate with the degree of airway inflammation (Jatakanon et al., 1998, Silkoff et al., 2000, Sittipunt et al., 2001, Fitzpatrick et al., 2009, Sandrini et al., 2010). However, whether $\mathrm{NO}^{\bullet}$ directly affects inflammation or is generated in response to inflammation to attenuate the reaction has not been clearly elucidated. In principle, our observation that airway epithelial cell activation induced by LPS, TNF- $\alpha$ and IFN- $\gamma$ is blunted by the upregulation of NOS is consistent with the latter hypothesis. Our data, showing an inhibitory effect of $\mathrm{NO}^{*}$ on IL-8 and MCP-1 synthesis and a stimulatory effect on ICAM-1 synthesis by human bronchial epithelial cells in vitro, might help dissect the role of this mediator in the pathogenesis of lung diseases in humans.

\section{ACKNOWLEDGEMENTS}

Supported by a grant from the Ministero dell'Università e della Ricerca Scientifica e Tecnologica of Italy (\# 2003062087).

\section{REFERENCES}

ABBA AA (2009) Exhaled Nitric Oxide in Diagnosis and Management of Respiratory Diseases. Ann Thorac Med 4:173-181.

AMRANI Y, LAZAAR AL, PANETTIERI RA (1999) Up-Regulation of Icam-1 By Cytokines in Human Tracheal Smooth Muscle Cells Involves an Nf-Kappa B-Dependent Signaling Pathway That is Only Partially Sensitive to Dexamethasone. J Immunol 163:2128-2134.

BALS R, HIEMSTRA PS (2004) Innate Immunity in the Lung: How Epithelial Cells Fight Against Respiratory Pathogens. Eur Respir J 23:327-333.

BLOOMFIELD GL, HOLLOWAY S, RIDINGS PC, FISHER BJ, BLOCHER CR, SHOLLEY M, BUNCH T, SUGERMAN HJ, FOWLER AA (1997) Pretreatment With Inhaled Nitric Oxide Inhibits Neutrophil Migration and Oxidative Activity Resulting in Attenuated SepsisInduced Acute Lung Injury. Crit Care Med 25:584-593.

BOVE PF, VAN DER VLIET A (2006) Nitric Oxide and Reactive Nitrogen Species in Airway Epithelial Signaling and Inflammation. Free Radic Biol Med. 41:515-27. Epub 2006 May 26.

CELI A, CIANCHETTI S, PETRUZZELLI S, CARNEVALI S, BALIVA F, GIUNTINI C (1999) Icam-1-Independent Adhesion of Neutrophils to Phorbol Ester-Stimulated Human Airway Epithelial Cells. Am J Physiol 277:L465-71.

CLANCY RM, LESZCZYNSKA-PIZIAK J, ABRAMSON SB (1992) Nitric Oxide, an Endothelial Cell Relaxation Factor, Inhibits Neutrophil Superoxide Anion Production Via a Direct Action on the Nadph Oxidase. J Clin Invest 90:1116-1121.

DE CATERINA $R$, LIBBY $P$, PENG HB, THANNICKAL VJ, RAJAVASHISTH TB, GIMBRONE MA, JR., SHIN WS, LIAO JK (1995) Nitric Oxide Decreases Cytokine-Induced Endothelial Activation. Nitric Oxide Selectively Reduces Endothelial Expression of Adhesion Molecules and Proinflammatory Cytokines. J Clin Invest 96:60-68.

DE SANCTIS GT, MACLEAN JA, HAMADA K, MEHTA S, SCOTT JA, JIAO A, YANDAVA CN, KOBZIK L, WOLYNIEC WW, FABIAN AJ, VENUGOPAL CS, GRASEMANN H, HUANG PL, DRAZEN JM (1999) Contribution of Nitric Oxide Synthases 1, 2, and 3 to Airway Hyperresponsiveness and Inflammation in a Murine Model of Asthma. J Exp Med 189:1621-1630.

DEVALIA JL, CAMPBELL AM, SAPSFORD RJ, RUSZNAK C, QUINT D, GODARD P, BOUSQUET J, DAVIES RJ (1993) Effect of Nitrogen Dioxide on Synthesis of Inflammatory Cytokines Expressed By Human Bronchial Epithelial Cells in Vitro. Am J Respir Cell Mol Biol 9:271-278. 
FITZPATRICK AM, BROWN LA, HOLGUIN F, TEAGUE WG (2009) Levels of Nitric Oxide Oxidation Products Are Increased in the Epithelial Lining Fluid of Children With Persistent Asthma. J Allergy Clin Immunol 124:990-6.e1-9.

JATAKANON A, LIM S, KHARITONOV SA, CHUNG KF, BARNES PJ (1998) Correlation Between Exhaled Nitric Oxide, Sputum Eosinophils, and Methacholine Responsiveness in Patients With Mild Asthma. Thorax 53:91-95.

KHARITONOV SA, BARNES PJ (2006) Exhaled Biomarkers. Chest. 130:1541-1546

KRISTOF AS, GOLDBERG P, LAUBACH V, HUSSAIN SN (1998) Role of Inducible Nitric Oxide Synthase in Endotoxin-Induced Acute Lung Injury. Am J Respir Crit Care Med 158:1883-1889.

LAAN M, BOZINOVSKI S, ANDERSON GP (2004) Cigarette Smoke Inhibits Lipopolysaccharide-Induced Production of Inflammatory Cytokines By Suppressing the Activation of Activator Protein-1 in Bronchial Epithelial Cells. J Immunol 173:4164-4170.

LANDER HM, SEHAJPAL P, LEVINE DM, NOVOGRODSKY A (1993) Activation of Human Peripheral Blood Mononuclear Cells By Nitric Oxide-Generating Compounds. J Immunol. 150:1509-1516.

LIU YC, KAO SJ, CHUANG IC, CHEN HI (2007) Nitric Oxide Modulates Air Embolism-Induced Lung Injury in Rats With Normotension and Hypertension. Clin Exp Pharmacol Physiol 34:1173-1180.

LOEWEN GM, TRACY E, BLANCHARD F, TAN D, YU J, RAZA S, MATSUI S, BAUMANN H (2005) Transformation of Human Bronchial Epithelial Cells Alters Responsiveness to Inflammatory Cytokines. BMC Cancer 5:145.

MA P, CUI $X$, WANG $S$, ZHANG J, NISHANIAN EV, WANG $W$, WESLEY RA, DANNER RL (2004) Nitric Oxide PostTranscriptionally Up-Regulates Lps-Induced Il-8 Expression Through P38 Mapk Activation. J Leukoc Biol 76:278-287.

MAY GR, CROOK P, MOORE PK, PAGE CP (1991) The Role of Nitric Oxide as an Endogenous Regulator of Platelet and Neutrophil Activation Within the Pulmonary Circulation of the Rabbit. Br J Pharmacol 102:759-763.

MIO T, ROMBERGER DJ, THOMPSON AB, ROBBINS RA, HEIRES A, RENNARD SI (1997) Cigarette Smoke Induces Interleukin-8 Release From Human Bronchial Epithelial Cells. Am J Respir Crit Care Med 155:1770-1776

MONCADA S, RADOMSKI MW, PALMER RM (1988) EndotheliumDerived Relaxing Factor. Identification as Nitric Oxide and Role in the Control of Vascular Tone and Platelet Function Biochem Pharmacol 37:2495-2501.

MURAD F (2006) Shattuck Lecture. Nitric Oxide and Cyclic Gmp in Cell Signaling and Drug Development. N Engl J Med. 355:2003-2011.
NATARAJAN R, GUPTA S, FISHER BJ, GHOSH S, FOWLER AAR (2001) Nitric Oxide Suppresses Il-8 Transcription By Inhibiting C-Jun NTerminal Kinase-Induced Ap-1 Activation. Exp Cell Res 266:203-212.

PRADO CM, LEICK-MALDONADO EA, YANO L, LEME AS, CAPELOZZI VL, MARTINS MA, TIBERIO IF (2006) Effects of Nitric Oxide Synthases in Chronic Allergic Airway Inflammation and Remodeling. Am J Respir Cell Mol Biol 35:457-465.

SANDRINI A, TAYLOR DR, THOMAS PS, YATES DH (2010) Fractional Exhaled Nitric Oxide in Asthma: An Update. Respirology 15:57-70.

SHERMAN TS, CHEN Z, YUHANNA IS, LAU KS, MARGRAF LR, SHAUL PW (1999) Nitric Oxide Synthase Isoform Expression in the Developing Lung Epithelium. Am J Physiol 276:L383-90.

SILKOFF PE, MARTIN D, PAK J, MARTIN RJ (2000) Exhaled Nitric Oxide and Induced Sputum Analysis as Markers of Airway Inflammation in Subjects With Copd. Chest 117:281S.

SITTIPUNT C, STEINBERG KP, RUZINSKI JT, MYLES C, ZHU S GOODMAN RB, HUDSON LD, MATALON S, MARTIN TR (2001) Nitric Oxide and Nitrotyrosine in the Lungs of Patients With Acute Respiratory Distress Syndrome. Am J Respir Crit Care Med 163:503510.

SPARKMAN L, BOGGARAM V (2004) Nitric Oxide Increases Il-8 Gene Transcription and Mrna Stability to Enhance Il-8 Gene Expression in Lung Epithelial Cells. Am J Physiol Lung Cell Mol Physiol 287:L76473

SPEYER CL, NEFF TA, WARNER RL, GUO RF, SARMA JV RIEDEMANN NC, MURPHY ME, MURPHY HS, WARD PA (2003) Regulatory Effects of Inos on Acute Lung Inflammatory Responses in Mice. Am J Pathol 163:2319-2328.

VAN DER VLIET A, EISERICH JP, CROSS CE (2000) Nitric Oxide: A ProInflammatory Mediator in Lung Disease? Respir Res. 1:67-72. Epub 2000 Aug 15.

VAN OVERVELD FJ, BULT H, VERMEIRE PA, HERMAN AG (1993) Nitroprusside, a Nitrogen Oxide Generating Drug, Inhibits Release of Histamine and Tryptase From Human Skin Mast Cells. Inflamm. Res. 38:C237-C238.

VILLARETE LH, REMICK DG (1995) Nitric Oxide Regulation of Il-8 Expression in Human Endothelial Cells. Biochem Biophys Res Commun. 211:671-676.

WATKINS DN, PERONI DJ, BASCLAIN KA, GARLEPP MJ, THOMPSON PJ (1997) Expression and Activity of Nitric Oxide Synthases in Human Airway Epithelium. Am J Respir Cell Mol Biol 16:629-639.

XIONG Y, KARUPIAH G, HOGAN SP, FOSTER PS, RAMSAY AJ (1999) Inhibition of Allergic Airway Inflammation in Mice Lacking Nitric Oxide Synthase 2. J Immunol 162:445-452. 
